\title{
A inclusão efetiva de todas Uma leitura da violência de gênero sob o prisma do mimetismo de René Girard e da ética da alteridade de Emmanuel Lévinas
}

\author{
Orientadora: Maria Clara Lucchetti Bingemer \\ Doutoranda: Maria Cristina Silva Furtado \\ Área de Concentração: Teologia Sistemático-Pastoral \\ Linha de Pesquisa: Religião e Modernidade \\ Projeto de Pesquisa: Místicos e Místicas do Século XX
}

O objetivo deste trabalho doutoral é possibilitar uma leitura teológica da 'violência de gênero' sob o prisma de René Girard e da ética da alteridade de Emmanuel Lévinas, de forma que se perceba que o ser humano liberto da supremacia masculina tem oportunidade de viver com maior liberdade a integração de suas dimensões e suas relações interpessoais. Uma nova forma de viver que o levará a conscientizar-se de que todos os seres humanos, independente de 'gênero', são amados por Deus. Dessa forma, embora não seja possível eliminar totalmente a 'violência de gênero', - pois a violência em si faz parte do ser humano -, ela pode ser amenizada, e as mulheres e o grupo LGBTTI virem a ser efetivamente incluídos, e terem participação ativa e decisória, na sociedade e na religião. Entretanto, isto só será possível através de uma atuação contundente da teologia procurando atualizar a temática referente: ao feminino, às interpretações bíblicas, e às reflexões teológicas a fim de promoverem a igualdade dos seres humanos e o respeito ao diferente. Com o intuito de proporcionar subsídios importantes para a teologia, esse trabalho doutoral foi realizado através de pesquisas interdisciplinares, trazendo ainda importantes aspectos dos 'estudos de gênero'. Procurou analisar com profundidade as teorias de René Girard e Emmanuel Lévinas, transportando-as para a 'violência de gênero', a fim de compreender, através da antropologia teológica, as causas principais desta violência, e buscar um caminho ético que leve a tão necessária mudança de paradigma.

Palavras-chave: Gênero. Violência de gênero. Inclusão. 